\title{
MINIATURE DECORATIVE NEEDLES FROM VIMINACIUM
}

\begin{abstract}
Although not numerous, the miniature decorative needles from Viminacium (comprising six examples divided into four types) deserve special attention. Actually, for a long time their purpose was a matter for academic discussion. This is why some examples were described as ear-rings, but because of their uncharacteristic wire part, this classification was soon abandoned. Different shaped heads (circle, pelta, swastika), made of thin metal sheets and a flat wire part with the end slightly bent into a hook, suggest that these kinds of objects represent decorative needles. They were made only of metal (silver and bronze). By virtue of their dimensions $(2.2$ to $3.3 \mathrm{~cm})$, they are different from classical decorative needles but, based on their other features, they are very similar to this kind of jewellery. Similar items from Siscia which, along with the Viminacium examples, represent the only finds of this kind discovered at one site in a large number. The miniature needles from Viminacium chronologically belong to the $2 n d$ and $3 r d$ century, which corresponds to the dating of the Siscia examples.
\end{abstract}

\section{KEY WORDS: DECORATIVE NEEDLES, BRONZE, SILVER, PLATE-SHAPED HEAD, VIMINACIUM, SISCIA}

The miniature decorative needles from Viminacium consist of a flat wire part, which was bent at the end, and a differently shaped head made of thin metal sheets. Their length measures between 2.2 and $3.3 \mathrm{~cm}$. In the plate, all basic data about each example is stated. ${ }^{1}$ In literature they are defined as ear-rings with an "S"-shaped hook, although they do not belong to this class of objects.

1 The drawings in the table were taken from the documentation (C-cards) and are shown in 1:1 scale.

* The article results from the project: IRS - Viminacium, Roman city and military legion camp - research of material and non material culture of inhabitants by using the modern technologies of remote detection, geophysics, GIS, digitalisation and $3 D$ visualisation (no 47018), funded by Ministry of Education, Science and Technological Development of the Republic of Serbia.
Moreover, it is obvious that this form of jewellery could not represent an ear-ring, since the wire part, which is flat and not bent, would easily slip off the ear. They were even considered semi-products and ear-ring examples which were thrown away because their wire parts were damaged during the production process (Koščević 1988: 17, T. IV, 72-82). Still, the new finds of this type show that one here is dealing with a special kind of jewellery, which was most likely used for overlap- 
ping or fastening parts of clothing. Only examples made of metal are known so far, mostly bronze, sometimes silver, while gold examples have not been found. Based on the shape of their heads, the miniature decorative needles from Viminacium are classified into four types.

\section{TYPE 1}

These needles have a plate-shaped round head and a soldered flat wire part which is slightly bent at the top in the shape of a hook. Two of needles of this type were found at Viminacium (C732, site "Pećine", cremation $\mathrm{G}_{1}-41$ ) (Golubović 2004: 86-87, Pl. V, 6; Миловановић 2007: 8990 , cat. nr. 409). In keeping with the grave goods found within this two-levelled grave of the "Mala Kopašnica - Sase" type, it can be concluded that a female person was buried here. ${ }^{2}$ An identical example is known from Siscia (Koščević, Makjanić 1995: 20-21, Pl. 41, 417). Two gold "ear-rings", with the same hook, but with a calotte-shaped head made from a metal sheet, which are on display in the Belgrade National Museum (Поповић 1996: 24, type VI 1/3, cat. 64) would, according to the wire part, more closely correspond to needles. However, the calotte-shaped head is identical to ear-rings whose hooks are clearly "S"-shaped. Consistent with the simple round heads, cut from

2 The needles were found in the area beneath the controlprofile. Other grave goods included: bronze plating of a chest with a preserved handle, nails and a part of the keyhole with a key C-717; two applications C-718 and 719; a ceramic pot $\mathrm{C}-720$; two iron nails $\mathrm{C}-721$; two bronze mirrors C-722 and C-724; an object made of bone C-723; a silver spatula and a fragment of a bronze spatula C-725 and $\mathrm{C}-735$; a bronze coin $\mathrm{C}-726$; two gold ear-rings C-727; two glass vessels C-728 and 728; a bronze fingerring $\mathrm{C}-729$; a bronze bracelet $\mathrm{C}-730$; a bronze handle (possibly of a mirror) C-731; two bronze needles C-733 and C-734; an amber pearl C-736; a bronze lock and the key-hole opening C-737 and 738; fragments of two bronze needles C-739; a sea-shell C-740; a fragment of a corroded iron object C-741; parts of iron chains with preserved nails C-742; parts of an iron tip C-743 and two bronze hinges C-744. bronze sheet, the needles from Viminacium represent the simplest shapes, from which some of the more complex types developed. Based on the age of the grave goods, the needles of this shape can be roughly dated to the $2^{\text {nd }}$ and $3^{\text {rd }}$ century.

\section{TYPE 2}

These needles have a plate-shaped round head with a jagged rim and with the wire part slightly bent at the top. Two examples from Viminacium (C-3820 and C-5255, site "Pećine", cremation $\mathrm{G}_{1}-309$ and inhumation G-1882) belong to this type. The first example is made of bronze, while the other is made of silver. The bronze needle, of which only the lower part remained preserved, was found in the two-levelled grave of the "Mala Kopašnica - Sase" type. ${ }^{3}$ The silver needle was found next to the knee bone of a poorly preserved skeleton. The bones were dislocated and so the long bones lay over the skull. There were no other grave goods. A pair of silver needles with a jagged plate-shaped head is known from Municipium DD (Fidanovski 1987-1988: 14, T. 5,1), as well as two examples made of bronze - one from Siscia, with a preserved white enamel slip (Koščević 1988: 17, T. IV, 74; Koščević, Makjanić 1995: 20-21, Pl. 41, 419) and the other from Intercissa (Alföldi 1957: T.LXXXVI, 6). Examples with a pelta-shaped head and a jagged edge from Siscia are numerous (Koščević, Makjanić 1995: 20-21, Pl. 41,420; 425-427) and date from the second half of the $2^{\text {nd }}$ to the end of the $3^{\text {rd }}$ century.

\section{TYPE 3}

One silver needle from Viminacium belongs to a special type (C- 6515, site "Pećine", cremation $\mathrm{G}_{1}-40$ ) with the head made of a met-

3 Next to the needle, a badly preserved and illegible bronze coin C-3819 was discovered. 
al sheet in a pelta-shape, while the wire part is identical to the previous examples. The remains of cremated bones were placed in a grave with a brick construction, while the needle was discovered in a shallow semi-spherical ceramic bowl which had been destroyed. The greatest number of needles with the pelta-shaped head originates from Siscia, with most of them possessing jagged edges (Koščević, Makjanić 1995: 20-21, Pl. 41, 420-428). The pelta motive, made using the perforating technique, was also applied on discoid fibulae from the Viminacium cemeteries, dating from the second half of the $2^{\text {nd }}$ century (Redžić 2006: T. XXIII, 255; Petković 2010: 176-175, cat. 967968 , T. XXXI, 10). It is known that plate-shaped fibulae are mostly ascribed to female costumes and therefore, the origin of needles with a pelta shaped head could be sought in this kind of jewellery.

\section{TYPE 4}

A bronze needle with a swastika shaped head and a thin wire with its end bent into a hook belongs to the fourth Viminacium type (C-303, site "Pirivoj", from the excavated soil). Due to the shape of its ends, the swastika, as a luck-bringing symbol, is often compared to the sun and its course across the sky, from the east to the west. On the head of the Viminacium needle, the ends circulate counter-clockwise, i.e. from the east to the west (Cirlot 1971: 322-323). Plate shaped fibulae with swastikas, which are known from Viminacium, are ascribed to production from the marginal Roman provinces along the Rhine and the Danube from the second third of the $2^{\text {nd }}$ century until the middle of the $3^{\text {rd }}$ century (Redžić 2006: T. XXIV, 266; Petković 2010: 185, cat. 995, T. XXXI, 8). At the "Pirivoj" site, a cemetery with cremations and skeletal burials was discovered, which chronologically belongs to the period from the end of the $2^{\text {nd }}$ to the end of the $3^{\text {rd }}$ century and the beginning of the $4^{\text {th }}$ century. This is why the needle is also treated as a part of a grave inventory, fitting into a wider chronological span. An identical example is known from Siscia (Koščević, Makjanić 1995: 20-21, P1. 41, 429).

\section{CONCLUSION}

Based on current understanding, it remains unknown whether miniature decorative needles were worn in pairs or separately. Only one pair of bronze needles is known (C-732, site "Pećine", cremation $\mathrm{G}_{1}-41$ ) from a cremation grave, while all of the other examples were single finds. This could be explained by the fact that the graves were mostly damaged and robbed. Their small dimensions and the shape of their heads point to the fact that they primarily had a decorative function, while the examples with the pelta or swastika shaped head also possessed a magical, protective function. Owing to their small dimensions, their practical purpose is reduced and they could only have been used for fastening some parts of clothing made of very thin textile, for example a scarf or a veil. This is why they could be considered parts of a female costume, like some form of head decoration. The similarity of types 1 and 2 with ear-rings with a flat wire part and a semi-spherical head cannot be ignored. A larger number of identical examples of miniature decorative needles are only known from Siscia, which is no coincidence since these two urban centres were also alike when other kinds of archaeological material are considered. One could also expect similar new finds within the borders of the Moesia province, which are not yet published or excavated. The chronological span of the Viminacium decorative needles is the $2^{\text {nd }}$ and $3^{\text {rd }}$ century. 


\section{BIBLIOGRAPHY}

Alföldi, R. M. et al. 1957

Intercisa (Dunapentele), II. Geichtesch der Stadt in der Römerzeit, Budapest: Archaeologia Hungarica, XXXVI.

\section{Golubović, S. 2004}

Jewellery and the Costume Decorations in the Cremation Graves from Viminacium, ANOAOS, Studies of the Ancient World 3: 79-90.

\section{Koščević, R. 1988}

Antički brončani predmeti sa jugoslovenskog dijela provincije Gornje Panonije, Doktorski rad, Filozofski fakultet, Univerzitet u Beogradu.

\section{Koščević, R. Makjanić, R. 1995}

Siscia Pannonia Superior, Finds and Metalwork Production - Terra sigillata. Zagreb: BAR International Series 621.

\section{Миловановић, Б. 2007}

Налази наушница у римским провинци-јама на територији Србије, ур. М. Кораћ, Археологија и природне науке, посебна издања 1, Београд: Центар за нове технологије и Археолошки институт Београд.

\section{Petković, S. 2010}

Rimske fibule u Srbiji od I do V veka n. e. posebna izdanja, knjiga 50, Beograd: Arheološki institut.

\section{Поповић, И. 1996}

Римски накит у Народном музеју у Београду, II Златан накит, Београд: Народни музеј Београд, Антика VI/2.

\section{Redžić, S. 2007}

Nalazi rimskih fibula na nekropolama Viminacijuma, ur. M. Korać, Arheologija i prirodne nauke, posebna izdanja 2, Beograd: Centar za nove tehnologije i Arheološki institut.
Fidanovski, S. 1987-1988

Nekropole municipijuma DD u svetlu novih istraživanja, Glasnik Muzeja Kosova, XV-XVI: 11-49.

Cirlot, J. E. 1971

A Dictionary of symbols, second edition (translated from the Spanish J. Sage), London: Taylor and Francis e-Library 2001.

\section{REZIME \\ MINIJATURNE UKRASNE IGLE IZ VIMINACIJUMA}

\section{KLJUČNE REČI: UKRASNE IGLE, BRONZA, SREBRO, PLOČASTA GLAVA, VIMINACIJUM, SISCIJA.}

Minijaturne ukrasne igle iz Viminacijuma sastoje se od tanke žice čiji je kraj blago povijen i od različito oblikovane glave od tanko iskucanog lima. Dužine su od 2,2 do 3,3 cm. Igle su podeljene na 4 tipa u zavisnosti od oblika glave koja je ravnog ili nareckanog ruba, u obliku pelte ili svastike. Uglavnom su iz grobova. Poznati su samo bronzani i srebrni primerci. Nošene su kao sastavni deo ženske nošnje na odeći ili glavi. Verovatno su nošene u paru, mada to još nije potvrđeno. Identični primerci poznati su iz Siscije, što nije slučajnost, jer postoji velika sličnost i u drugoj vrsti materijala između Siscije i Viminacijuma. Na osnovu grobnih priloga i analognih nalaza iz Siscije, ukrasne minijaturne igle iz Viminacijuma hronološki su ograničene na period od 2. do 3. veka. 


\begin{tabular}{|c|c|c|c|c|c|}
\hline Type & Decorative needle & C-number & Material & Location & Site \\
\hline & & 732 & Bronze & G1-41 & Pećine \\
\hline & & 382 & Bronze & G1-309 & Pećine \\
\hline & & 5255 & Silver & G-1882 & Pećine \\
\hline 3 & & 6515 & Silver & G1-40 & Pećine \\
\hline 4 & & 303 & Bronze & $\begin{array}{c}\text { from the } \\
\text { excavated soil }\end{array}$ & Pirivoj \\
\hline
\end{tabular}

Plate of decorative pins from Viminacium 